\title{
消化管粘膜における透過性え進シグナルの伝達機構
}

\author{
村上正裕·村西昌三 \\ 京都薬科大学・製剤学教室 $\quad 607$ 京都市山科区御陵中内町 5

\section{Possible Mechanism of Signaling for Permeability Enhancement in Intestinal Mucosa}

\author{
Masahiro Murakami and Shozo Muranishi \\ Department of Biopharmaceutics, Kyoto Pharmaceutical University \\ Yamashina, Kyoto 607 (Japan)
}

The epithelial cell sheet in the gastrointestinal mucosa is a permselective sophisticated membrane, which serves as a potent permeation barrier to water-soluble and large molecular weight xenobiotics. Fatty acids such as oleic acid and capric acid efficiently enhance the intestinal absorption of poorly absorbed drugs due to the transient reduction of the barrier resistance. However, the mechanisms have not been completely elucidated and their effective and safe use should be desired in drug delivery. It was proposed that these fatty acids could enhance the permeation of drugs by perturbing the lipid bilayer of brush-border membrane. However, it seems unlikely to explain that they increase the mucosal permeation of macromolecular compounds which cannot pass through cell membranes. We have found that the permeability enhancement by the fatty acids is temperature-dependent with being maximal at $37^{\circ} \mathrm{C}$, and that it is inhibited by the membrane-permeable $\mathrm{SH}$-modifiers, corresponding with the reduction in sulfhydryl content in the brush-border membrane, and high concentration of potassium ion in the lumen. The sulfhydryl modification of brush-border membrane inhibited the oleic acid-induced increase in membrane fluidity in the SH-protein fraction but not in the lipid bilayer. In addition, $\mathrm{W}-7$, a specific calmodulin inhibitor, significantly inhibited the oleic acid-induced increase in membrane permeability, suggesting the possible roles of calmodulin-dependent protein kinases in the mechanism underlying the permeability enhancement of the intestinal mucosa.

The results discussed in this study suggest that a signal from the action of oleic acid on the brushborder membrane is transmitted via some subcellular molecular systems to the cell skeleton to increase the mucosal drug permeability. However, further detail studies are needed to estabilish this mechanism.

Key words : permeability enhancement, SH-protein, oleic acid, calmodulin-dependent. 
Table 1 Classes of absorption-enhancing agents for intestinal drug delivery

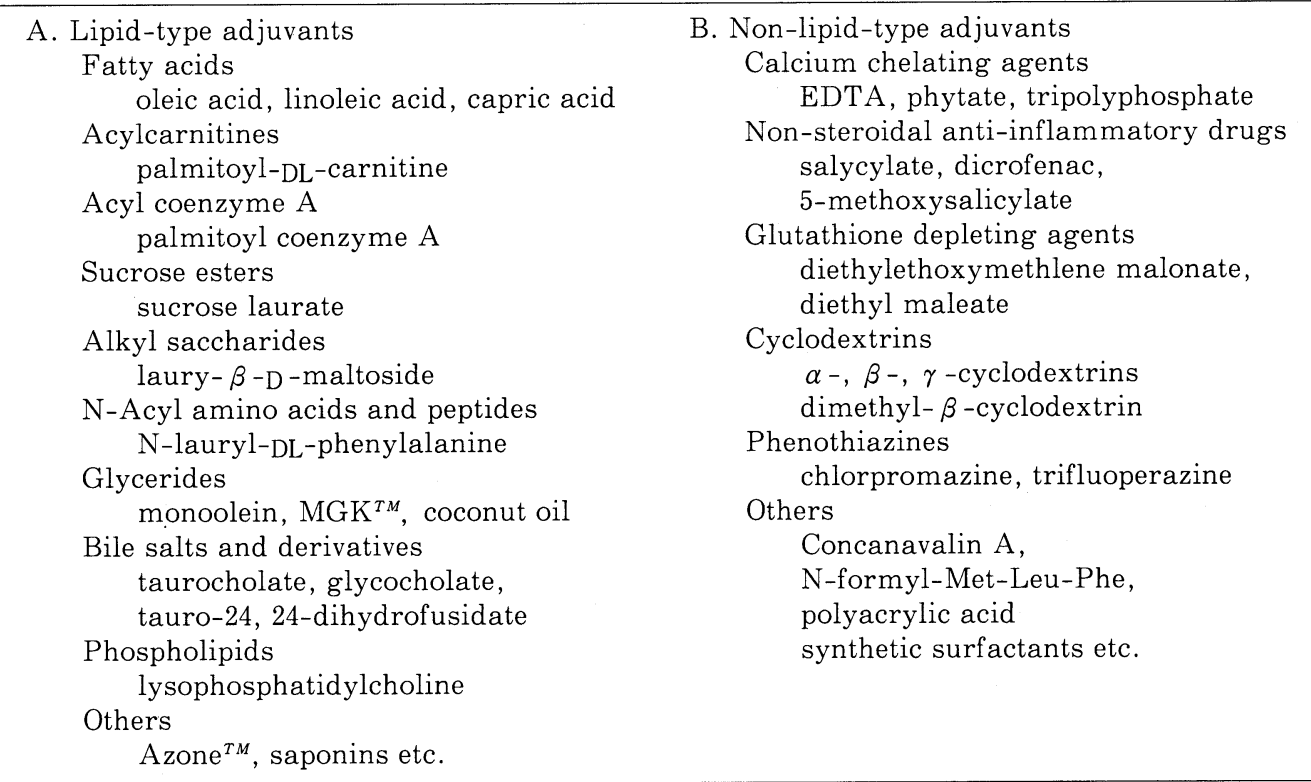

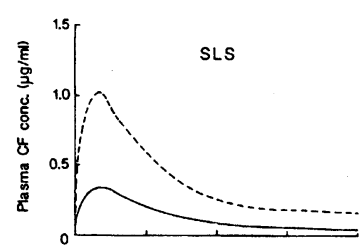
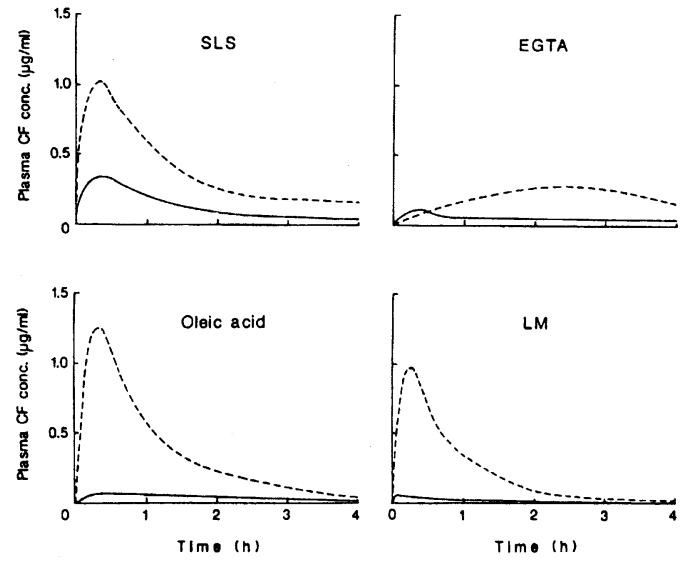

Fig. 1. Plasma profiles of $\mathrm{CF}$ after treatments with $10 \mathrm{mM}$ SLS solution, 10 $\mathrm{mM}$ oleic acid-HCO-60 solution, 25 mM EGTA solution, $5 \mathrm{mM}$ LM solution. $\cdots$, CO-administration; , free $\mathrm{CF}$ administration after pretreatment for $30 \mathrm{~min}$, then washing with saline.

\section{1.はじめに}

近年のめざましいバイオテクノロジーの進歩は, 臨床 上重要なホルモンやサイトカインをはじめとする生理活 性ペプチドの安定した供給を保証し, その治療薬として の開発におおいに寄与しつつある.これらぺプチド性薬
物の生体内への薬物の送達法 (Drug Delivery System, DDS) は, その有効性および安全性の見地から, 医学, 薬学をはじめ工学, 農学など多岐にわたる分野で 活発な研究がなされている. とくに薬剤学の領域では, 患者の負担を軽減し, 在宅ケアを可能にするなどの観点 から, 注射以外の投与法にもとづくDDS の開発研究が 注目を集めている. ところが, ペプチド性薬物は一般に 水溶性が高く, 高分子のものが多いため, 消化管をはじ めとする粘膜からの吸収性にとぼしいという難点があ る. この障害を克服するためのアプローチの 1 つとして 吸収促進剂の利用があげられる ${ }^{1)}$. われわれは脂肪酸や モノグリセリドのような天然の脂質類のなかに, 高い消 化管吸収促進作用を示すものを見出し ${ }^{2)}$, その発見当初 より, 種々の応用的研究ならびに吸収促進機構の解明に 関する基礎的研究を行ってきた ${ }^{3)}$. とくに後者は, 吸収 促進剤の安全性と最適な利用法を確立するうえで重要な 意味をもつものと考える.

ここでは, 消化管吸収促進剂の特徵について述べると ともに, 脂肪酸, 特に不飽和長鎖脂肪酸の消化管吸収促 進作用の発現機構に関する検討の結果, 現在までに得ら れた知見を総括して紹介する. 


\section{2. 吸収促進剤とその特徵}

\section{1 吸収促進剂の条件}

「吸収促進剤 (absorption enhancers)」ということ ばは，「皮膚や粘膜などの体表面に作用し，その透過障 壁能を一時的に低減することによって，適用部位からの 難吸収性薬物の吸収を増大する補助剤 (adjuvants)」 の総称として用いられている，薬物吸収は溶解性や安定 性を改善することによってもみかけ上増加するが，この 場合は薬物自体の吸収性（膜透過性）が変化するのでは ないので，このために使用した界面活性剤や安定化剂な どは吸収促進剂の範疇には属さないといえる，各部位の 特性 $^{3)}$ に応じて, 有効な促進剂は必然的に異なってくる が，消化管において吸収促進作用の報告されている主な 物質を Table 1 にまとめた. 中鎖脂肪酸であるカプリ ン酸を吸収促進剂として坐剂に配合し，アンピシリンや セフチゾキシムのような本来吸収性の低い薬物の製剤化 が成功している，一方，吸収促進剤としては膜傷害性の 強いものや膜に不可逆的な变化を与えるものは不適当と いえる. Fig. 1 に示すように，オレイン酸では, 腸管腔 内から洗浄除去することによって，粘膜の透過性は速や かに元のレベルに回復する，また，同じアルキル鎖を有 する界面活性剤を用いた場合でも, lauryl maltoside

Table 2 Criteria of absorption enhancers

(1) 皮膚や粘膜など生体側に作用する

(2) 生体適合性 (biocompatibility) が高い

(3) 吸収促進作用が傷害性に基づくものではない

(4) 吸収促進作用が可逆的である

(5) 薬理作用を示さない

\section{(A)}

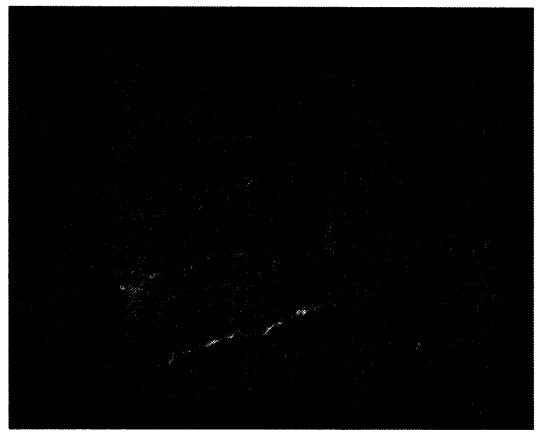

(LM) では吸収促進作用が速やかに消失するのに対し て, sodium laurylsulfate (SLS) の場合では粘膜の障

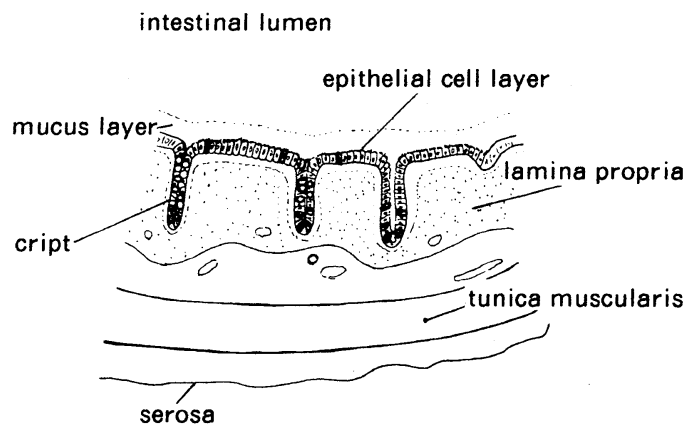

transcellular route

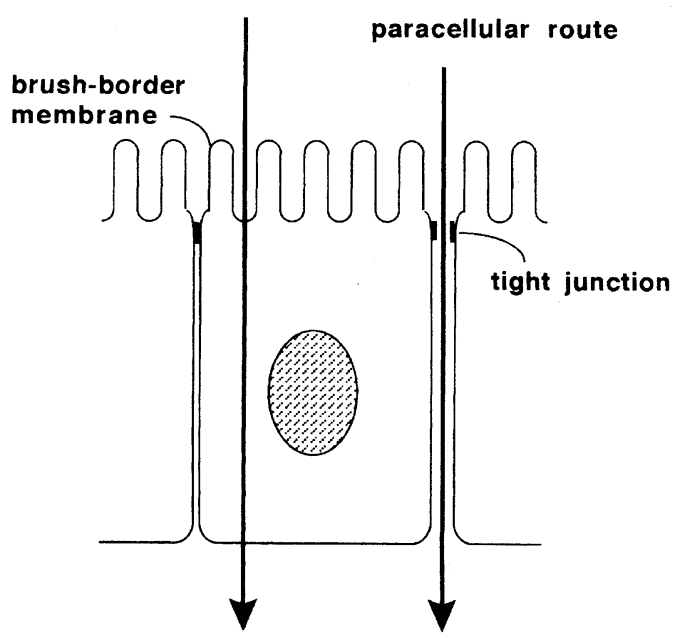

Fig. 2. Schematic diagrams of intestinal mucous structure and routes of drug permeation

(B)

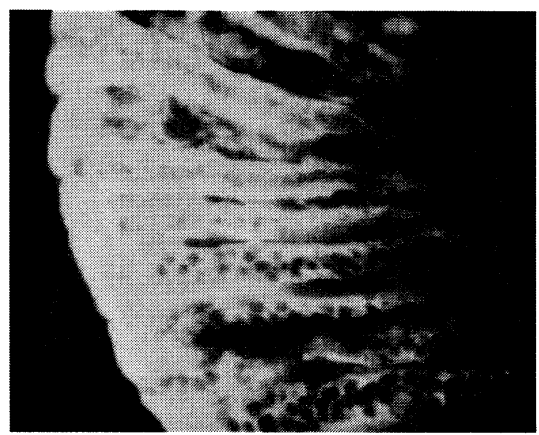

Fig. 3. Fluorescence microphotograph of rat colon 5 min after the administration of FD-70 with (A) or without (B) linoleic acid-HCO-60 mixed micelles 
Table 3 AUC after large intestinal administration of carbxyfluorescein (CF) in various formulations

\begin{tabular}{lc}
\hline \multicolumn{1}{c}{ Composition } & $\mathrm{AUC}_{0-4 h}(\mu \mathrm{g} \cdot \mathrm{min} / \mathrm{m} l)^{a)}$ \\
\hline None (control) & $2.9 \pm 0.4$ \\
$4 \mathrm{mM}$ HCO-60 & $2.2 \pm 0.4^{N S}$ \\
$30 \mathrm{mM}$ capric acid & $14.8 \pm 2.5^{* c)}$ \\
$30 \mathrm{mM}$ stearic acid & $2.7 \pm 0.5^{N S}$ \\
$30 \mathrm{mM}$ oleic acid & $47.8 \pm 1.8^{* * * b}$ \\
$30 \mathrm{mM}$ linoleic acid & $\left.51.3 \pm 1.3^{* * * b}\right)$ \\
$30 \mathrm{mM}$ stearic acid+4 mM HCO-60 & $29.1 \pm 5.6^{* c)}$ \\
$30 \mathrm{mM}$ oleic acid+4 $\mathrm{mM} \mathrm{HCO}-60$ & $\left.81.9 \pm 9.6^{* * c}\right)$ \\
$30 \mathrm{mM}$ linoleic acid+4 mM HCO-60 & $88.2 \pm 14.2^{* * c)}$ \\
\hline
\end{tabular}

a) : Data are presented as mean \pm S. E. of at least 3 rats. Comparisons vs. the control were carried out using Student's t-test

b) : or Cochran-Cox test

c) : ${ }^{*}, \mathrm{p}<0.05 ;{ }^{* *}, \mathrm{p}<0.01 ;{ }^{* * *}, \mathrm{p}<0.001 ;^{N s}$, not significant.

壁性が回復しておらず, この濃度でSLS は膜に不可逆 的な傷害を引き起こすことが示唆される. 実際, 光学顕 微鏡レベルの組織学的検討の結果は, これらの結果とよ く符号することが認められている5). Table 2 にわれわ れが吸収促進剤の基準とする主な条件を示した.

\section{2 消化管の構造と吸収促進剤の作用}

消化管粘膜を介する物質透過は, 上皮細胞層の構造お よび機能により制御されており, 水溶性や高分子性薬物 にとっては, この上皮細胞層を介する透過が吸収の律速 過程となっている. とくに腸管腔表面に面する吸収上皮 細胞の刷子縁膜および上皮細胞間の接着部 (tight junction) が最大の透過障壁となっている (Fig. 2).した がって, 薬物の透過経路としては, 刷子縁膜を透過する 細胞内経路 (transcellular route) と, 細胞間接着部を 透過する細胞間隙経路 (paracellular route) とが存在 し, 吸収促進剤はこれらの双方, あるいは, いずれかの 透過性を一時的に高めるはたらきがあるものと考えられ る. Fig. 3 は, 細胞膜非透過性の蛍光標識高分子デキス トラン (FD-70) を用い, ラット大腸粘膜におけるリ ノール酸の透過性亢進作用を調べた結果 ${ }^{6)}$ である.リ ノール酸を作用させた場合の粘膜組織の蛍光染色像は, FD-70 の細胞間隙経路を介した透過を示している. Table 1 からは, 吸収促進剤として脂肪酸関連化合物, す なわち脂質のなかに有効なものが数多く見出されている ことがわかる. また, 生物物理学的検討からは, これら の脂質がいずれも生体膜の物理化学的性質に影響を及ぼ
すことが示されてきた．このように機構面からは, 消化 管吸収促進剤を脂質のように膜作用に基づくものと, そ れ以外のメカニズムによるものとに大別することができ る. たとえば, カルシウムキレート剤は, 細胞接着因子 であるカルシウムイオンを粘膜組織より奪うことで, 細 胞間隙経路の薬物透過性を高めることが示唆されてお り, 後者の例としてあげられる. 最近の電気生理学的手 法を用いた検討7)では, EDTA は細胞間隙経路の透過 性を, また, ジクロフェナックは細胞内経路の透過性を, 比較的選択的に六進することが示されている. しかしな がら, 消化管吸収促進剤のなかで, その作用機構の全容 が明らかにされているものはきわめて少ない，吸収促進 剂を用いた場合には, 薬物の吸収が吸収促進剂の作用強 度に依存してきまるので, このような吸収促進剤の作用 機構を明らかにすることは, 薬物の体内への送達速度と 量を制御し, その効果的かつ安全な利用を行ううえで重 要であるといえる.

\section{3. 脂肪酸の吸収促進作用}

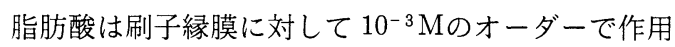
することから, その吸収促進作用は非特異的な膜作用に 基づくものと考えてよい.このため物性や構造の類似し た化合物についても, 脂肪酸と類似した吸収促進作用が 認められている5.8.9)。 また, 脂肪酸の吸収促進作用は 胃から直腸部へと, 消化管下部の方がより顕著に現れ $3^{(0)}$ 。このような部位差の原因については, 解剖学的 
にみた腸管の長さ当たりの有効吸収面積の差に基づくも のと考えられているが, これらの部位では生理学的にも かなりの相違があり，明確な解答は得られていない，ま た, 脂肪酸の吸収促進効果の発現はきわめて迅速であり, 血中から消化管腔方向への薬物透過 (exsorption) も同 時に六進することから, 膜動輸送などの特殊輸送系は関 与していないものと考えられる. 同濃度で比較した場合, 脂肪酸の中では, 不飽和長鎖脂肪酸が最も強い吸収促進 作用を示し, 中鎖脂肪酸にも比較的強い吸収促進作用が

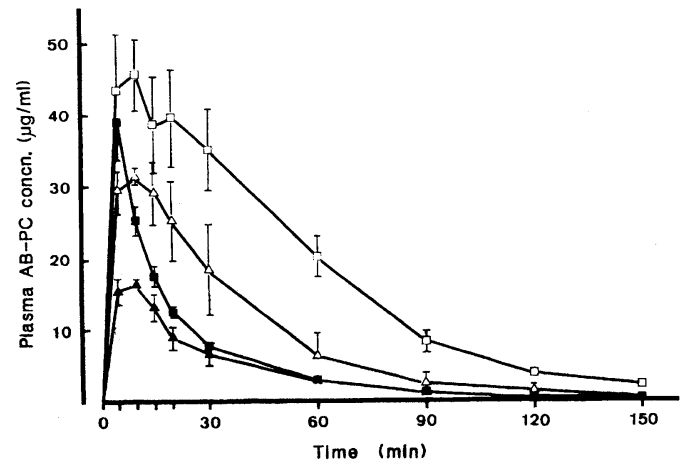

Fig. 4. Plasma concentration of ampicillin after rectal administration in rats. Witepsol H-5 suppositories with 5\% linoleate sodium ( $\square$ ), $5 \%$ linoleic $\operatorname{acid}(\triangle)$ and without enhancer $(\mathbf{\Delta})$. Microenema with $5 \%$ linoleate sodi$\mathrm{um}(\boldsymbol{\square})$. Means $\pm \mathrm{SE}$ of at least 3 animals.
認められた (Table 3). このときの粘膜透過性の亢進 は可逆的であり，脂肪酸による前処理が無効であること から, in vivo では脂肪酸の粘膜移行に伴い透過性が変 化するものと考えられる. 実際, in vitro ではオレイン

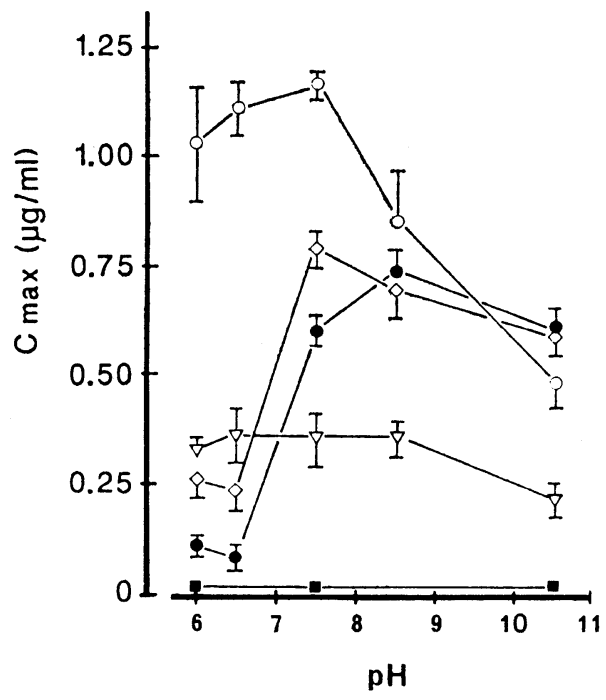

Fig. 5. $\mathrm{pH}$ dependence on absorption-enhancing effect of fatty acids in the large intestine

$\bigcirc: 30 \mathrm{mM}$ oleic acid/4 mM HCO-60;

: $30 \mathrm{mM}$ oleic acid; $\diamond, 30 \mathrm{mM}$ linoleic acid; $\nabla, 30 \mathrm{mM}$ capric acid; $\mathbf{\square}$, free CF. Vertical bars represent standard errors of mean for at least 3 rats.

Table 4 Effects of various lipids in $10 \mathrm{mM}$ taurocholate mixed-micellar solution on rat large intestinal absorption of streptomycin

\begin{tabular}{lcc}
\hline \multicolumn{1}{c}{ Lipid } & $\begin{array}{c}\text { Plasma concentration } \\
\text { at } 15 \mathrm{~min}(\mu \mathrm{g} / \mathrm{m} l)\end{array}$ & $\begin{array}{c}\text { Ability to induce } \\
\text { cell fusion }\end{array}$ \\
\hline None & $<1.5$ & - \\
Taurocholate & $<1.5$ & - \\
Caprylic acid $\left(\mathrm{C}_{8: 0}\right)$ & $<1.5$ & Negative \\
Lauric acid $\left(\mathrm{C}_{12: 0}\right)$ & 5.0 & Positive \\
Palmitic acid $\left(\mathrm{C}_{16: 0}\right)$ & $<1.5$ & Negative \\
Oleic acid $\left(\mathrm{C}_{18: 0}\right)$ & 14.9 & Positive \\
Linoleic acid $\left(\mathrm{C}_{18: 2}\right)$ & 14.4 & Positive \\
Monoolein & 14.2 & Positive \\
Diolein & $<1.5$ & Moderate \\
Triolein & $<1.5$ & Negative \\
Oleyl alcohol & $<1.5$ & Positive \\
Methyl oleate & $<1.5$ & Positive \\
\hline
\end{tabular}

a) reported by Ahkong et al. (1973) 
Table 5 Effect of various lipids on motion parameters of 5nitroxide stearic acid incorporated into liposomal membranes at $25^{\circ} \mathrm{C}$

\begin{tabular}{lcc}
\hline \multicolumn{1}{c}{ Lipid $^{a}$} & 2T, (gauss) & Order parameter \\
\hline None & 49.6 & 0.57 \\
Lauric acid & 47.2 & 0.52 \\
Myristic acid & 48.0 & 0.54 \\
Palmitic acid & 48.2 & 0.54 \\
Stearic acid & 49.0 & 0.55 \\
Palmitoleic acid & 47.0 & 0.51 \\
Oleic acid & 47.4 & 0.52 \\
Linoleic acid & 46.8 & 0.50 \\
Linolenic acid & 46.7 & 0.50 \\
Monoolein & 49.7 & 0.58 \\
Monopalmitin & 51.0 & 0.60 \\
Monostearin & 50.4 & 0.60 \\
\hline
\end{tabular}

a Equimolar mixture

酸の組織蓄積量の経時的变化と, 粘膜透過性の変化とが よく対応することを確かめている. すなわち, 吸収促進 剤の作用は局所的であり,この部位にそのとき共存して いる薬物のみが粘膜を透過できることになる.このため, ゲル化剤などの基剤で, 薬物および吸収促進剤の腸管に 沿った方向への拡散や希釈, 両者の分離を防ぐことで吸 収促進の効率の向上が認められる. Witepsol H-5 を基 剤とするアンピシリン坐剂に, リノール酸ナトリウムを 配合してラットに投与した場合, $5 \%$ の配合で筋注時に ほぼ匹敵するバイオアベイラビリティを示した (Fig. $4)^{11}$. 一方, 長銷脂肪酸の吸収促進作用は, 胆汁酸塩 や界面活性剤と混合ミセルを形成することによって, さ らに顕著に増大する．これは，脂肪酸分子の会合性を低 下し, 粘膜表面への拡散性を高めることと, 混合ミセル とすることによるみかけの $\mathrm{pKa}$ の上昇によることが示 唆されている ${ }^{12)}$. Fig. 5 に脂肪酸および混合ミセルと 溶液 $\mathrm{pH}$ との関係を調べた結果を示す.このように中鎖 脂肪酸と比較して, 長鎖不飽和脂肪酸の吸収促進作用は $\mathrm{pH}$ の影響を強く受けるが, 混合ミセルとすることに よって生理的 $\mathrm{pH}$ 領域での変動はほとんど消失し, 安定 した高い促進効果を得ることができる.

\section{4. 脂肪酸による粘膜透過性の亢進機構}

\section{1 膜構成成分との相互作用}

脂肪酸をはじめとする両親媒性の化合物は, 生体膜成
分である脂質やタンパク質と相互作用して, 膜構造や物 性, 機能に様々な影響を与える可能性がある，脂質の吸 収促進作用が明らかになるにつれて，作用機構面でしだ いに注目されたことは, Table 4 に示すように，消化管 吸収促進作用を示す脂質 ${ }^{13)}$ 之細胞膜融合を誘発する作 用の強い融合性脂質 (fusogenic lipids) ${ }^{14)}$ との間に多 くの一致がみられたことである.このことは, 細胞骨格 系を含めた膜の, かなりダイナミックな变化を伴う生体 膜融合現象 ${ }^{15)}$ と, 膜透過性穴進作用との間に共通した 機構の存在することを暗示するものであった．実際，膜 融合に先立って, 細胞膜透過性は六進することが知られ ており，比較的高分子のものまで透過可能となる．この ことは, 少なくとも細胞膜経路の透過性亢進作用を説明 するものと考えられた. ESR の検討 ${ }^{16)}$ で各脂質を作用 させた場合の order parameter (Table 5) は, リポ ソーム膜の透過性変化ならびに Table 4 の in vivo にお ける結果と高い相関性を示すことが示された.

一方, 刷子縁膜に取り込まれた脂肪酸は, 細胞骨格系 を含めた膜のタンパク質成分とも相互作用することが考 えられる. そこで, ラットの結腸粘膜より得た刷子縁膜 標本を種々の蛍光プローブで標識し, 蛍光偏光解消 法 $^{17)}$ により膜流動性（秩序性）の変化を調べることに よって, オレイン酸と膜成分との相互作用を調べた. $\mathrm{DPH}$ は脂質相の疎水領域の流動状態をモニターし，ま た, FITC はタンパク質のアミノ基と, NPM は SH 基 とそれぞれ結合して, タンパク質相の流動性の変化が検 
(A) $\mathrm{DPH}$

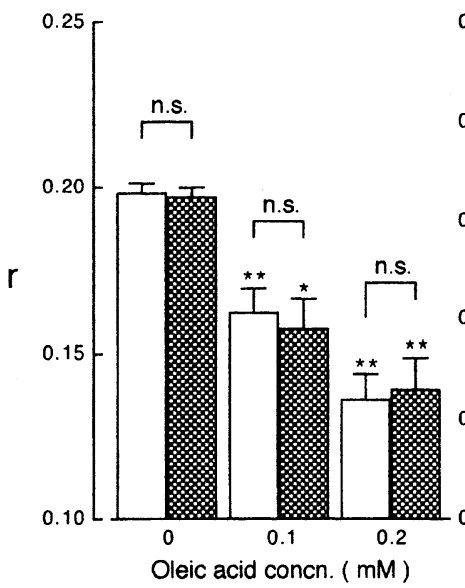

(B) NPM

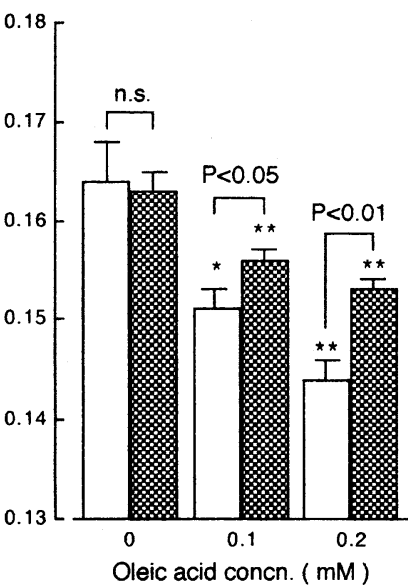

(C) FITC

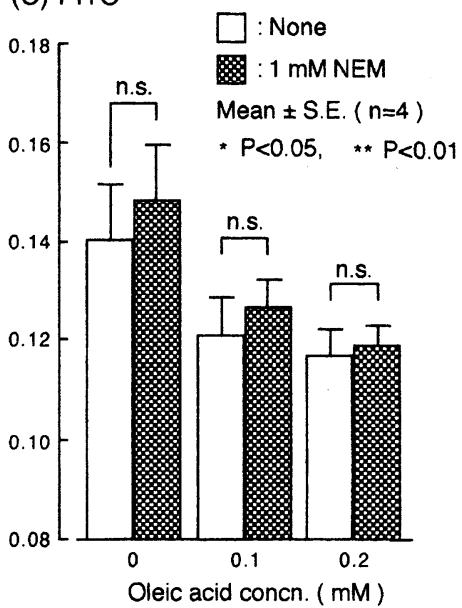

Fig. 6. Effects of oleic acid and $N$-ethylmaleimide on fluorescence anisotropy (r) of various fluorophores in rat colonic brush-border membrane

DPH, 1,6-diphenyl 1,3,5-hexatriene; NPM, $N$ - (1-pyrene) maleimide; FITC, fluorescein isothiocyanate

(A)

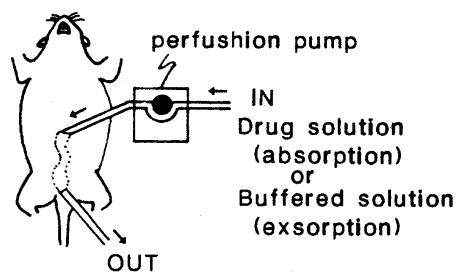

(B)

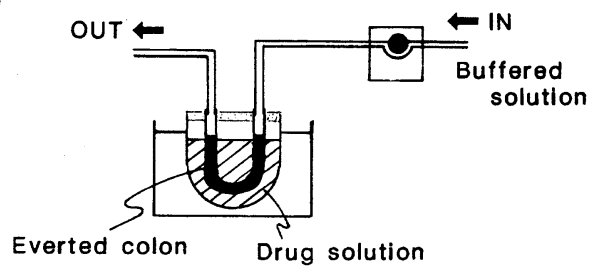

Fig. 7. Schematic diagrams of in situ intestinal perfusion technique (A) and in vitro everted loop method (B)

出できる，縦軸には蛍光異方性 (fluorescence anisotropy, $\gamma$ ）を算出してプロットした. 数值の高い方が 膜の秩序性が高い（流動性が低い）ことを意味してい る. Fig. 6 に示すように，オレイン酸は脂質相の流動性 を濃度依存的に顕著に増大させることが示され，先の ESR スペクトルによる検討と一致する結果が得られた. しかもオレイン酸は, 濃度依存的に NPM の $\gamma$ 值を有 意に低下させ，また，FITCの $\gamma$ 值も減少させる傾向を

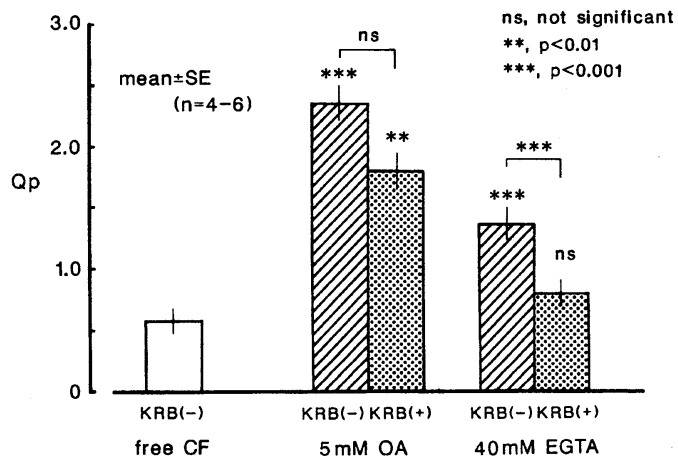

Fig. 8. Effect of divalent cations on the colonic permeation induced by absorption enhancers. Krebs-Ringer buffered solution containing $1.3 \mathrm{mM} \mathrm{CaCl}_{2}$ and $\left.1.2 \mathrm{mM} \mathrm{MgCl} \mathrm{MRR}_{2}(+)\right)$ or not $(\mathrm{KRB}(-))$.

示し, 膜のタンパク質相の流動性も顕著に増大させるこ とが明らかとなった．同様の結果は，最近中鎖脂肪酸に ついても報告されている18).

一方, 膜タンバク質の $\mathrm{SH}$ 基を修飾する $N$-ethylmaleimide (NEM) で膜を処理することによって, こ のオレイン酸と $\mathrm{SH}$ 基膜タンパク質との相互作用のみ選 択的に抑制され，膜の脂質相に対するオレイン酸の作用 には全く影響の見られないことが見出された (Fig. 6).

このように脂肪酸の刷子縁膜流動性に及ぼす作用は, 
その吸収促進機構の一部を説明するものと考えられる。 しかしながら, 刷子縁膜透過性の変化からは，前述した 細胞膜非透過性高分子の粘膜透過性の増大などを直接説 明することは困難である。このため消化管においては， 吸収促進剤による薬物透過性の亢進を, あくまで上皮細 胞層という組織膜を介する現象としてとらえる必要があ るものと考えられる.そこで, Fig. 7 に示すような, ラッ

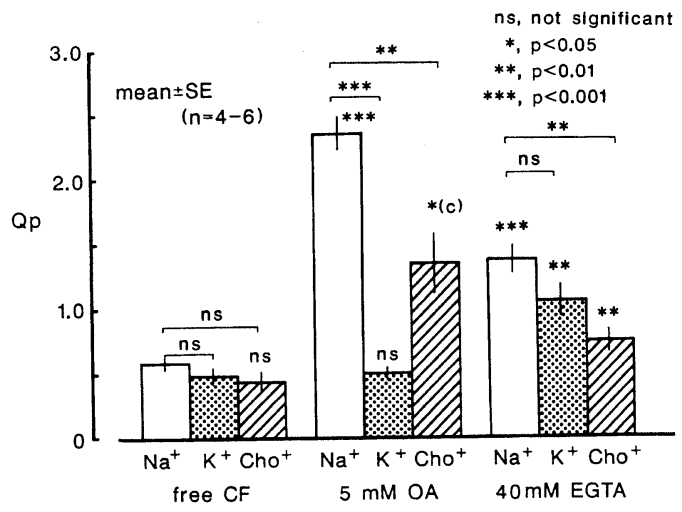

Fig. 9. Effect of monovalent cations on the colonic permeation of $\mathrm{CF}$ produced by absorption enhancers

\section{(A) $20 \mathrm{mM}$ EGTA}

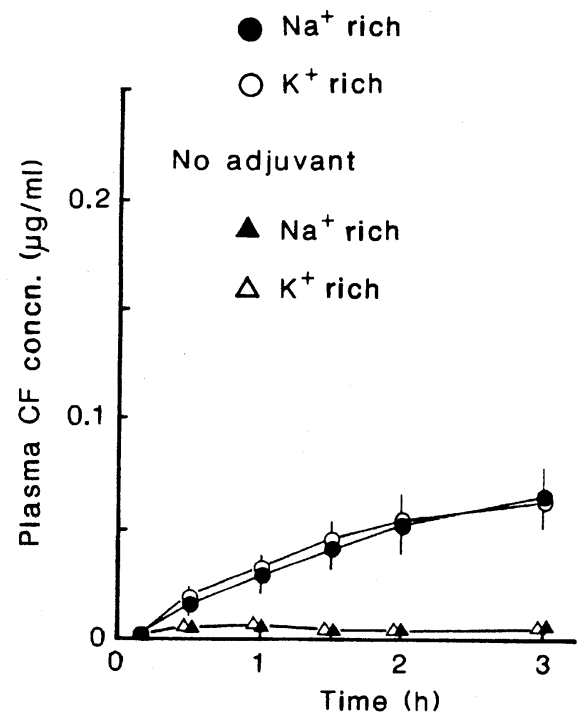

膜 (MEMBRANE), Vol. 19 No. 4 (1994)

265

卜結腸部における in situ 灌流法あるいは摘出反転腸管 を用いた in vitro 灌流法により，さらに詳細な検討を 行なった，なお，粘膜透過性の変化は，水溶性で消化管 における安定性の高い蛍光色素 6-carboxyfluorescein (CF) をプローブとしてモニターした.

\section{2 カチオンの影響}

前述したように, 細胞接着因子であるカルシウムイオ ンは, 細胞間隙経路の透過性制御における重要な因子の 1つである.Fig. 8 は，オレイン酸ならびにEGTA に よる粘膜透過性の六進に及ぼす共存 2 価カチオンの影響 をin vitroにおいて調べた結果を示している，縦軸に は粘膜透過性の指標として, 投与後 60 分までに粘膜側 から漿膜側灌流液中へ透過した CF の累積量 (Qp 值) を求め,プロットした．薬液および灌流液には $\mathrm{pH} 7.4$ の Krebs-Ringer 緩衝液を用いたが，標準条件として は，粘膜側薬液溶液中の 2 価カチオンは除いた。粘膜側 薬液に 2 価カチオンを添加することによって，オレイン 酸では有意な抑制は認められなかったのに対して, EGTA ではほぼ完全にその粘膜透過性六進作用が阻害され た。一方, 漿膜側灌流液の 2 価カチオンを除くと, 両促 進剤の作用発現濃度は有意に低下し，オレイン酸では

(B) $5 \mathrm{mM} \mathrm{OA}$

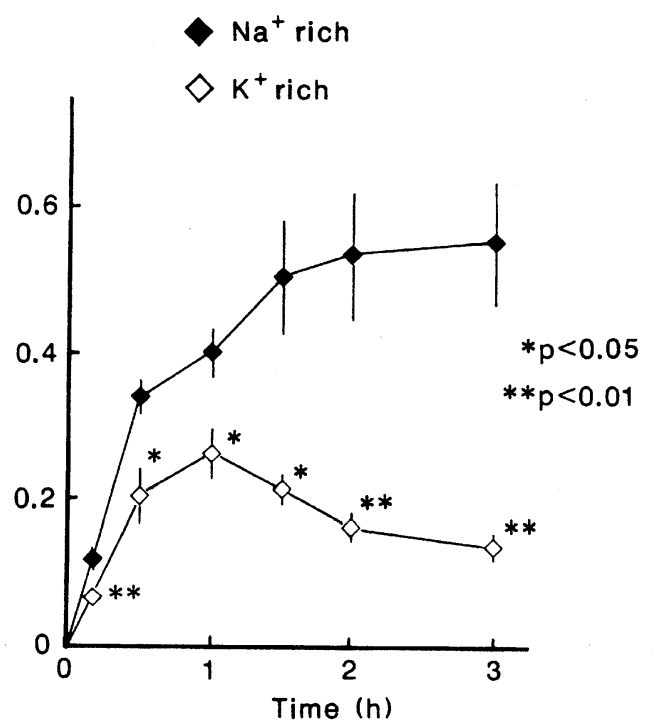

Fig. 10. Effet of coexistent monovalent cations in the lumen on the colonic absorption of CF induced by absorption enhancers. 
Table 6 Effect of potassium ion and temperature on the in vitro colonic permeation of $\mathrm{CF}$ induced by caprate

\begin{tabular}{cccccc}
\hline Enhancer & KRB & Temperature & QP value & N & $P^{b)}$ \\
\hline \multirow{2}{*}{$10 \mathrm{~m}$ M sodium caprate } & $\mathrm{Na}^{+}$ & $37^{\circ} \mathrm{C}$ & $2.76 \pm 0.24$ & 5 & (control) \\
& $\mathrm{K}^{+}$ & $37^{\circ} \mathrm{C}$ & $0.99 \pm 0.28$ & 5 & 0.01 \\
& $\mathrm{Na}^{+}$ & $25^{\circ} \mathrm{C}$ & $0.91 \pm 0.13$ & 4 & 0.001 \\
\hline
\end{tabular}

a) Data are represented as the mean \pm S. E.

b) Comparisons vs. control were performed by Student's t-test.

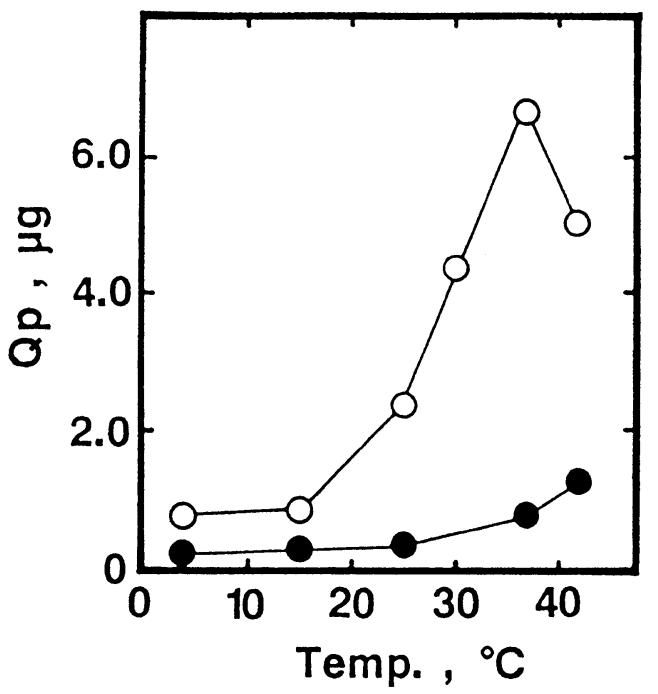

Fig. 11. Temperature dependence of adjuvant effect of oleic acid in vitro. $\mathrm{O}, 10 \mathrm{mM}$ oleic acid/HCO-60; free $C F$.

$1 / 2$ 程度の濃度で, また, EGTA では $1 / 10 〜 1 / 20$ の濃 度で作用が認められた (data not shown). 標準条件に おける両促進剤の有効濃度は, in vivo のそれに近いも のであることから, EGTA のようなカルシウムキレー 卜剂は, 組織からカルシウムなどの 2 価カチオンを奪う ことで促進作用を発現するものと考えられるが, in vivo では血漿からの 2 価力チオンの供給の影響によって 促進作用の発現が緩和され, 有効濃度が引き上げられる ものと推察された. また, Tight junction の分子構築 は完全には明らかではないが, 上皮細胞の側底膜の接着 には, それぞれカルシウム要求性のカドヘリンおよびイ ンテグリンが寄与していることが明らかとされてお $り^{19)}$ ，高濃度のキレート剂による作用は，上皮細胞の 㓦離を引き起こし, 不可逆的な粘膜透過性の変化をもた らすものと考えられる. Fig. 9 は, 粘膜側緩衝液中のナ
トリウムイオンを，カリウムまたはコリンイオンで置換 することにより,1価のカチオンの影響を検討した結果で ある. カリウムイオンによる置換によって，EGTA の 透過性六進作用には有意な減少が認められなかったが, オレイン酸の透過性六進作用の発現は顕著に抑制される ことが明らかとなった。 これに対して，コリンイオンに よる置換は, オレイン酸ならびに EGTA による粘膜透 過性の増大を有意に抑制したが，その阻害率には差が認 められなかった：また，いずれの置換においても，CF 自体の透過性には有意な変化は認められなかった. Fig. 10 に示すように, in vivo における検討結果は, これら in vitro の結果とよく一致することが示された. さらに, カプリン酸についても同様に, カリウムイオンによる粘 膜透過性の亢進作用の抑制がみられた (Table 6).

このように, オレイン酸は共存 2 価カチオンの影響を ほとんど受けず, Tight junction からカルシウムを取 り除くことによって透過性を六進する EGTA のような キレート剤とは明らかに作用が異なることが示された。 また粘膜側に高濃度のカリウムイオンを存在させること によって, 脂肪酸による粘膜透過性の増大が抑制された ことから, その刷子縁膜の流動性の変化に基づく膜透過 性の増大は, 細胞内のカリウムレベルの一時的な低下を もたらし，これが組織全体の透過性の増大を誘導するも のと推察される.こうした細胞内カリウム濃度の变化は, 上皮細胞の容積調節において重要な役割を果たしている ことが知られているが20), 組織からのカリウムイオン の流出が, 脂質層を介する拡散によるものか, 細胞内力 ルシウムイオン濃度の変化に伴う膜のカリウムチャンネ ルの開閉や，イオン輸送系の活性変化によるものかは不 明である.

\section{3 タンパク質の関与}

オレイン酸の透過性亢進作用に及ぼす系の温度の影響 をin vitroにおいて調べた結果を Fig. 11 に示した. 
Free の CF では温度の上昇に伴い, 透過性に上昇傾向 が認めら机が,オレイン酸による粘膜透過性の増大は, $37^{\circ} \mathrm{C}$ を最適値とする明らかな温度依存性を示すことが 明らかとなった．このことはオレイン酸の粘膜透過性六 進作用の発現に, タンパク質の関与する可能性を示唆し ている.また，オレイン酸とは細胞内での代謝や吸収動 態の異なるカプリン酸についても同様の温度依存性が認 められたことから (Table 6), 脂肪酸自体の細胞内代謝 物は関与せず,これら脂肪酸による透過性の亢進刺激は,

Table 7 Comparison of effect of various sulfhydryl modifiers on the transmucosal permeability of $\mathrm{CF}$ in the presence of oleic acid

\begin{tabular}{lccc}
\hline \multicolumn{1}{c}{ Pretreatment } & & $\mathrm{Qp}^{a)}$ & $\%$ of Control \\
\hline $\begin{array}{l}\text { None (Control) } \\
\text { (impermeable) }\end{array}$ & 4.09 & 100 \\
PCMPS $^{b}$ ) & $5 \mathrm{mM}$ & 4.00 & 99 \\
(permeable) & & & \\
$\mathrm{PCMB}^{c)}$ & $5 \mathrm{mM}$ & 2.49 & 61 \\
$\mathrm{HgCl}_{2}$ & $5 \mathrm{mM}$ & 2.65 & 65 \\
$N$-Ethylmaleimide & $5 \mathrm{mM}$ & 1.06 & 26 \\
Iodoacetamide & $5 \mathrm{mM}$ & 2.86 & 70 \\
Diethylmaleate & $5 \mathrm{mM}$ & 4.58 & 112 \\
\hline
\end{tabular}

a) Cumulative amount of $\mathrm{CF}$ permeated across the mucosa for 90 min after dosing.

b) $p$-chloromercuriphenylsulfonate

c) $p$-chloromercuribenzoic acid
刷子縁膜において他の分子機構に伝達されるものと推察 された. さらに, 先に示した刷子縁膜小胞における検討 結果は, この粘膜透過性の変化に刷子縁膜の $\mathrm{SH}$ 基タン

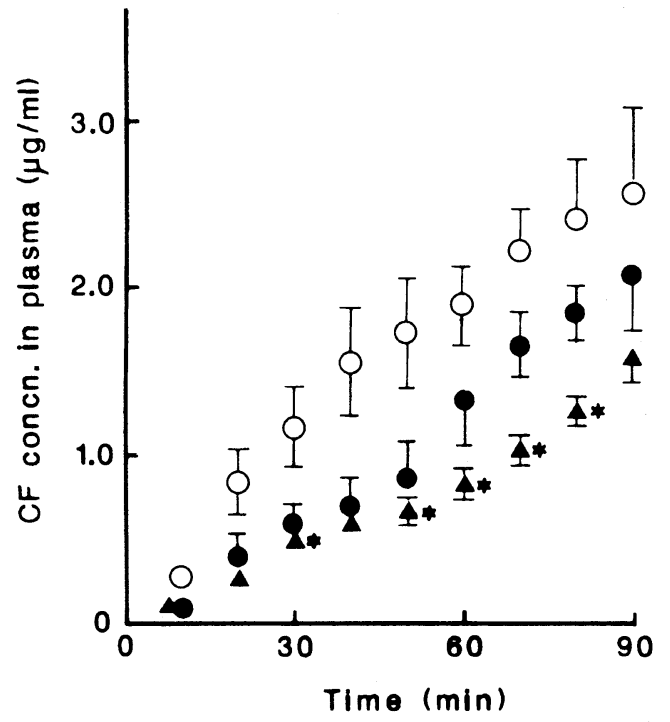

Fig. 12. Plasma concentration-time curves during the in situ single-pass perfusion of $\mathrm{CF}$ in the presence of oleic acid. Effect of pretreatment of the mucosa with $0.1 \mathrm{mM}$ diamide (O);

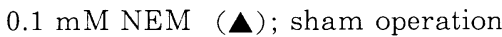
with the medium ( $\bigcirc$ ) for $15 \mathrm{~min}$.

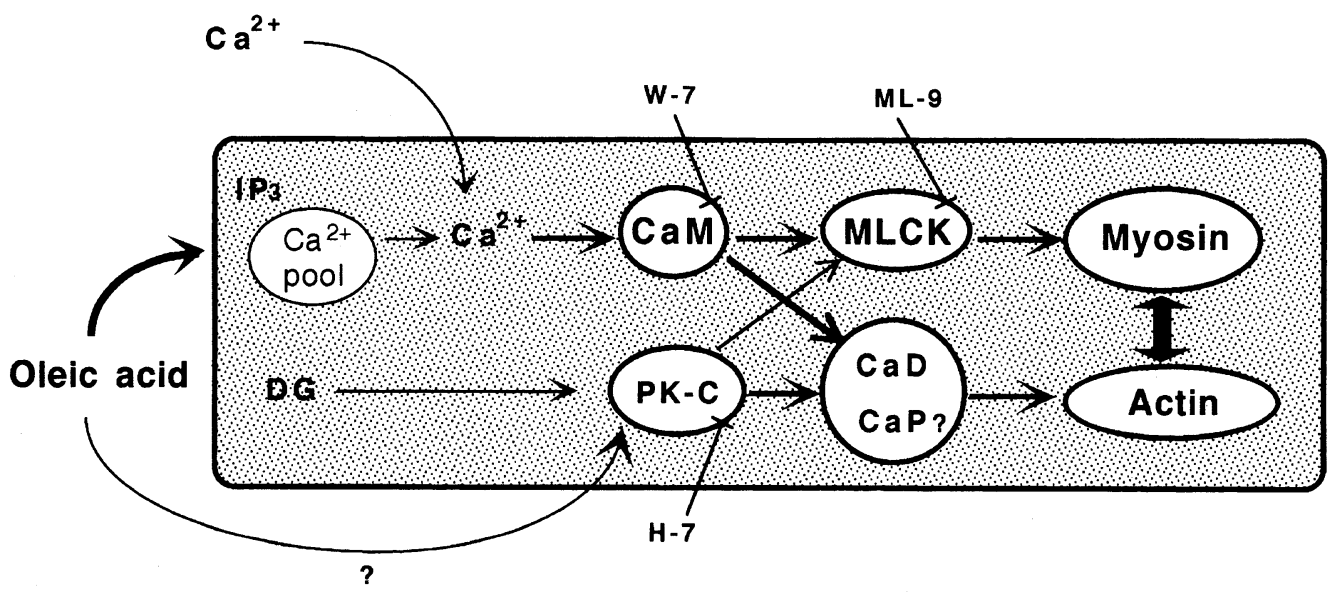

Fig. 13. Schematic representation of the regulation of contraction and relaxation responces of actin-myosin fibers by cell signal conduction systems.

CaM, calmodulin; MLCK, myosin light-chain kinase; PK-C, protein kinase C; CaD, caldesmon; CaP, calponin.

$\rightarrow$, activation; $\longrightarrow$, inhibition; $\longleftrightarrow$, interaction. 
パク質の関与することを示唆している. そこで, 種々の 膜タンパク質の修飾剂を用いて粘膜透過性の变化との関 連をin vitroにおいて調べた ${ }^{21)}$. Table 7 は, SH 基修 飾剂による前処理効果を調べた結果を示している.オレ イン酸による粘膜透過性の増大は, 膜透過性の $\mathrm{SH}$ 基修 飾剤によって著しく阻害されることが明らかとなり,な

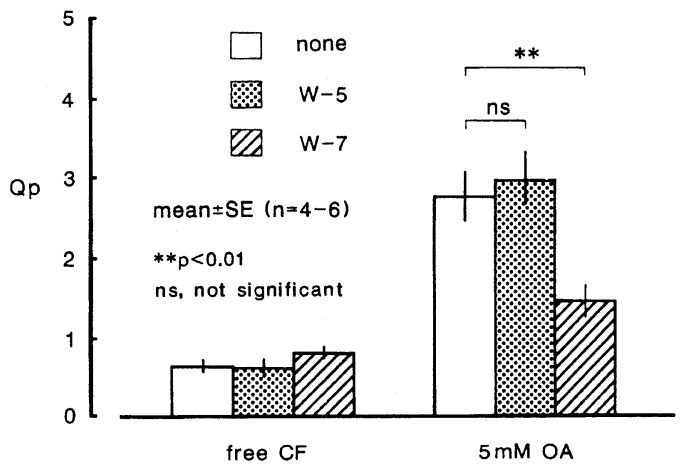

Fig. 14. Effect of calmodulin inhibitors on the colonic permeation of CF produced by oleic acid.
かでも NEM による阻害作用が最も強く，膜非透過性 の水銀剤である PCMPS および細胞内の非タンパク質 性の $\mathrm{SH}$ 基の特異的枯渴剤である diethyl maleate, 種々のアミノ基修飾剤には阻害作用が認められなかっ た。 さらにこの阻害作用の SH 基依存性は, 可逆性の SH 基架橋剤である diamide および還元剤である dithiothreitol を用いた検討によって確かめられた ${ }^{22)}$. また, このときの粘膜透過性の変化は, 刷子縁膜中の夕 ンパク質性 $\mathrm{SH}$ 基濃度の変化とよく対応することが示さ れた ${ }^{21,22)}$.オレイン酸の吸収促進作用に対する $\mathrm{SH}$ 基 修飾剤の抑制効果は, Fig. 12 に示すようにin vivo に おいても確かめられ，オレイン酸の吸収促進作用が, 刷 子縁膜のSH 基タンパク質を介して発現する可能性が示 唆された.こうした膜の $\mathrm{SH}$ 基 reactive な機能性タン パク質としては, カルシウムポンプ $\left(\mathrm{Ca}^{2+} / \mathrm{Mg}^{2+}-\mathrm{AT}\right.$ Pase) のような膜内在タンパク質の他に, アクチンや ミオシンなどの細胞骨格系タンパク質などがあげられ る.さらに, NEM や diamide には膜タンパク質のク ラスター形成の阻害 ${ }^{23)}$ や細胞骨格系タンパク質に対す る収縮阻害作用 ${ }^{24)}$ などが報告されており関連性が注目
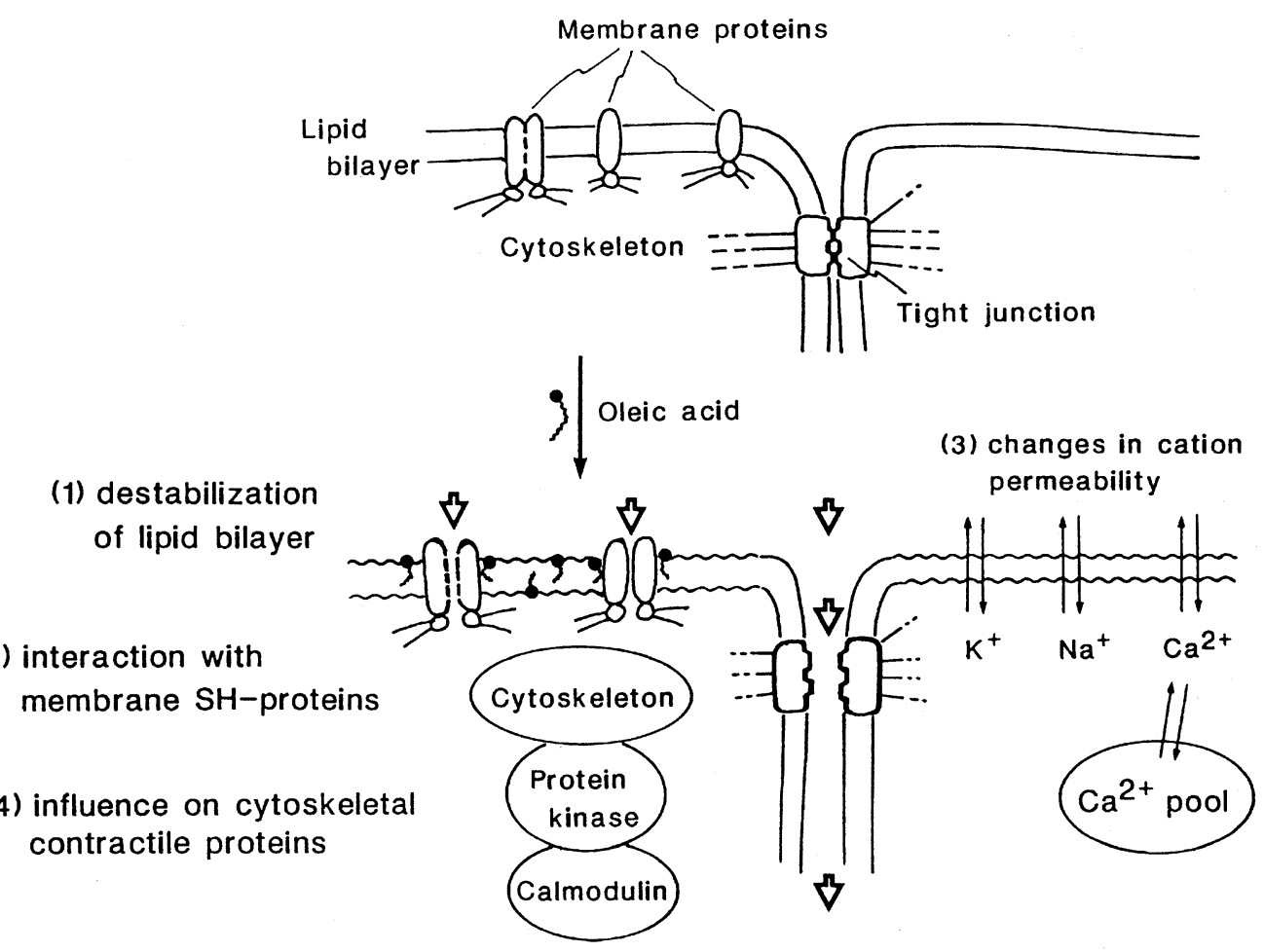

Fig. 15. Proposed model for oleic acid-induced enhancement in the colonic absorption. 
された.

\section{4 細胞内骨格系タンパク質の寄与}

上皮細胞の形態維持ならびに細胞間隙経路の透過性制 御において，アクチンーミオシン系の細胞骨格系タンパ ク質が重要な役割を果たすことが示されてきた ${ }^{25}$ ) (Fig. 13). 一方, 生体膜と細胞骨格系タンパク質との結合や, 接着部の分子構築と構造タンパク質の構造維持, 収縮性 タンパク質の収縮活性などを抑制する分子機構の解明が 進むにつれて，とくにカルシウムイオンにより活性が調 節されている一連のタンパク質リン酸化酵素の重要性が 注目された ${ }^{26)}$ 。そこで, 種々の細胞内情報伝達系の特 異的阻害剂を用いて検討を行った. Fig. 14 にオレイン 酸の透過性亢進作用に及ぼすカルモジュリン阻害剤の効 果を調べた結果を示した. $\mathrm{Ca}^{2+}$-カルモジュリン複合 体には，腸管の刷子縁膜を収縮させる活性を有すること が報告されている27).オレイン酸による粘膜透過性の 増大は，W-7によって有意に抑制されるが，その Negative control である W-5によって影響を受けないこと が明らかとなった．また，W-7 および W-5 自体は, こ の濃度ではいずれも粘膜透過性には影響を及ぼさなかっ た. カルモジュリン依存性の結合タンパク質には, ミオ シン軽鎖キナーゼ (MLCK), カルデスモン $(\mathrm{CaM})$, プ ロテインキナーゼ II, MRKCS など複数の存在が知ら れているが, 現在のところ MLCK に対する阻害剤にも, 透過性穴進作用を抑制する効果を認めている.このよう に, カルモジュリンならびに MLCK の阻害剤にオレイ ン酸による粘膜透過性変化に対する有意な抑制効果が見 出されたことは, 細胞内カルシウム情報伝達系を介して, 活性の調節されている細胞骨格系タンパク質の関与を示 唆するものと思われる.

以上の検討結果をまとめると, 脂肪酸による粘膜透過 性の亢進においては Fig. 15 に示すような図式を想定す ることができる．ただし，細胞骨格系タンパク質の機能 は, C キナーゼあるいは $\mathrm{cAMP} / \mathrm{cGMP}$ を伝達物質と する情報伝達系によっても調節されており, 特定の伝達 系の寄与を証明するためには, 脂肪酸による粘膜透過性 の変化と伝達物質のレベルやタンパク質リン酸化の程度 の経時変化などとの相関を詳細に調べる必要があるもの と考えている.

\section{5. おわりに}

脂肪酸のような脂質類の吸収促進作用は，その脂質二 重層に及ぼす物理化学的作用に基づく膜透過性の六進か ら説明されてきたが，本研究により，この膜で生じた透 過性亢進のシグナルは, $\mathrm{SH}$ 基タンパク質を介してなん らかの細胞内分子機構に伝えられ, 細胞間隙経路を含め た粘膜上皮細胞層全体の透過性の増大が引き起こされる ということを示唆することができた。 この細胞内分子機 構の有力な候補としては, カルシウム情報伝達系があげ られるが，現時点でそれを確定する証拠は得られていな い，他の類似する吸収促進剤の作用機構との共通性を含 めて全容の解明にはさらに詳細な検討が必要である。こ うした細胞内の現象を検討する手段として, 最近行われ ている上皮細胞の単層培養系における検討 ${ }^{28,29)}$ が, 有 力な情報をもたらすものとして期待される．ただし，薬 物の消化管における詳細な吸収動態は完全には明らかと されておらず，吸収上皮細胞のみならずクリプト細胞の 吸収における寄与 ${ }^{30)}$ なども念頭におくと，できるだけ in vivo に近い系にフィードバックさせて検討を進めて いく必要があると思われる。一方, confocal microscopic imaging technique や stopped flow analysis などの手法の導入も有力であり, 最新の分析技術や解析 手段を駆使することによって, 粘膜透過性の変化や薬物 の局所における動態を, 細胞内のイオンや情報伝達物質 のレベルの変化とともにリアルタイムでとらえていくこ とも可能であるものと考えている.

専門の諸兄からのご意見など睗われば幸甚でありま す.

\section{文献}

1) S. Muranishi, A. Yamamoto, H. Okada: "Biological Barriers to Protein Delivery" (K. L. Audus, T. J. Raub. ed.) p. 199, Plenum Press, New York (1993).

2) S. Muranishi, Y. Tokunaga, K. Taniguchi, H. Sezaki: Chem. Pharm. Bull., 25, 1159 (1977).

3) S. Muranishi: Crit. Rev. Ther. Drug Carrier System, 7, 1 (1990).

4) 村西昌三 : 膜, 15, 11 (1990).

5) M. Murakami, Y. Kusanoi, K. Takada, S. Muranishi: Int. J. Pharm., 79, 159 (1992).

6) S. Muranishi, K. Takada, H. Yoshikawa, M. Murakami: "Delivery System for Peptide $\mathrm{Dr}$ ugs" (S. S. Davis, L. Illum, E. Thomlinson, ed.) p. 177, Plenum Press, New York (1986). 
7) S. Yamashita, H. Saitoh, K. Nakanishi, M. Masada, T. Nadai, T. Kimura: J. Pharm. Pharmacol., 37, 512 (1985).

8) M. Murakami, K. Takada, S. Muranishi: Int. J. Pharm., 31, 231 (1986).

9) E, L. LeCluyse, L. E. Appel, S. C. Sutton, Pharm, Res., 8, 84 (1991).

10) K. Taniguchi, S. Muranishi, H. Sezaki: Int. J. Pharm., 4, 219 (1980).

11）村上正裕, 鈴木幸雄, 村西昌三 : 薬剤学, 51, 166 (1991).

12) 村上正裕, 福井 博, 村西昌三 : 薬剤学, 53,176 (1993).

13) N. Muranushi, M. Kinugawa, Y. Nakajima, S. Muranishi, H. Sezaki: Int. Pharm., 4, 271 (1980).

14) Q. F. Ahkong, D. Fisher, W. Tampion, J. A. Lucy: Biochem. J., 136, 147 (1973).

15) 笹川 滋, 本田憲治 : 膜, 6, 310 (1981).

16) N. Muranushi, N. Takagi, S. Muranishi, H. Sezaki: Chem. Phys. Lipid, 28, 269 (1981).

17) R. F. Chen, R. L. Bowman, Science, 147, 729 (1965).

18) H. Kajii, T. Horie, M. Hayashi, S. Awazu: J. Pharm. Sci., 75, 475 (1986).

19) S. Muranishi, M. Murakami : "Topics in Ph- armaceutical Sciences 1991” (D. J. A. Crommelin, ed.) p. 139, F. I. P., The Hague (1992).

20）永㴊昭良：実験医学, 9, 819 (1991).

21) B. Sarkadi, J. C. Parker: Biochim Biophys, Acta, 1071, 407 (1991).

22) M. Murakami, K. Takada, T. Fujii, S. Muranishi: Biochim. Biophys. Acta, 939, 238 (19 88).

23) M. Murakami, K. Takada, S. Muranishi: Biochim. Biophys. Acta, 1117, 83 (1992).

24) R. Karlsson, U. Lindberg: Exp. Cell. Res., 157, 95 (1985).

25) J. L. Madara: Amer, J. Physiol., 253, C171 (1987).

26) M. E. Duffey, B. Hainau, S. Ho, C. J. Bentzel, Nature, 294, 451 (1981).

27) T. C. S. Keller, III, M. S. Moosker: J, Cell Biol., 95, 943 (1982).

28) X. Boulenc, E. Marti, H. Joyeux, C. Roques, Y. Berger, G. Fabre: Biochem. Pharmacol., 46, 1591 (1993).

29) E. K. Andeberg, T. Lindmark, P. Artursson: Pharm. Res., 10, 857 (1993).

30) K. C. Pedley, R. J. Naftalin: J. Physiol., 460, 525 (1993).

（受付 1994 年 2 月14日） 